Boise State University

ScholarWorks

Public Policy and Administration Faculty

Publications and Presentations

Summer 2019

\title{
State Preemption of Local Authority: Explaining Patterns of State Adoption of Preemption Measures
}

Luke Fowler

Boise State University

Stephanie L. Witt

Boise State University

This is a pre-copyedited, author-produced PDF of an article accepted for publication in Publius: The Journal of Federalism following peer review. The version of record:

Fowler, L. \& Witt, S.L. (2019). State Preemption of Local Authority: Explaining Patterns of State Adoption of Preemption Measures. Publius: The Journal of Federalism, 49(3), 540-559.

is available online at doi: 10.1093/publius/pjz011 
This is an author-produced, peer-reviewed version of this article. The final, definitive version of this document can be found online at Publius:

The Journal of Federalism, published by Oxford University Press. Copyright restrictions may apply. doi: 10.1093/publius/pjz011

\title{
State Preemption of Local Authority: Explaining Patterns of State Adoption of Preemption Measures
}

\author{
Luke Fowler \\ Associate Professor and MPA Director \\ School of Public Service \\ Boise State University \\ lukefowler@boisestate.edu \\ Stephanie L. Witt \\ Professor \\ School of Public Service \\ Boise State University \\ switt@boisestate.edu
}

\begin{abstract}
State preemption of local policymaking has attracted increasing attention from scholars, public officials, and citizens, as states have prevented local governments from boosting the minimum wage, regulating firearms, and barring certain forms of discrimination, among other policies. Although scholars have examined the legal dimensions of state preemption and analyzed preemption in specific areas, we lack a comprehensive account of which states have adopted preemption laws and why some states are more active than others in adopting them. Using a dataset drawing on preemption legislation in seventeen policy areas, we test support for competing explanations for variation in adoption of state preemption measures. Our general conclusion is that political factors are more significant than institutional features in explaining state preemption activity. More specifically, and consistent with expectations, we find preemption measures are more likely to be adopted by Republican-controlled states. We also find that legislative professionalism, political culture, and home-rule status are correlated with the prevalence of preemption measures.
\end{abstract}

Recently, state preemption of local policies has attracted attention from journalists, federalism scholars, and groups interested in specific policy areas impacted by preemption (Greenblatt 2015, 2016; Mosher 2017; Riverstone-Newell 2017; Berman 2018). In the most basic sense, preemption occurs when higher-level governments pass laws restricting the policy authority of lower-level governments (DuPuis, Langan, McFarland, Panettieri, and Rainwater 2017). Most commonly, scholars view this from a federal-state perspective, whereby Congress limits the policy discretion of state governments (e.g., Rabe 2008; SoRelle and Walker 2016). In recent decades, however, states have increasingly passed laws reining in innovative local governments (Riverstone-Newell 2017). For instance, in the first few months of 2019, legislation was introduced to prevent local gun registries in South Dakota (Sneve 2019), local bans on plastic bags in Oklahoma (Burke 2019), and local regulation of vacation rentals and plastic straw bans in Florida (Haughey 2019; Grimm 2019). Also in 2019, the New Mexico legislature adopted a law preempting local governments from enacting right-to-work ordinances (Associated Press 2019). These recent instances of proposed and enacted preemption laws are a continuation of trends from 2018 when states such as Minnesota and Texas saw a deluge of preemption bills introduced as part of a widespread effort to assert state dominion over local governments (Jayson 2018; Nelson 2018).

Although there is a fairly well-developed body of literature that approaches preemption from a legal perspective, research from social science perspectives, especially political science and public administration, is limited (Buzbee 2008; Riverstone-Newell 2017; Hicks et al. 2018). As local governments are becoming more important players in the U.S. federal system (Feiock and Scholtz 2009; Langan and McFarland 2017; Briffault 2018; Phillips 2018), this has prompted new and interesting research questions concerning the distribution of authority between state and local governments and which level of government should wield policymaking power. Existing scholarship on state preemption tends to focus on specific policy areas (e.g., firearm limitations, minimum wage requirements, and labor policies) or on single states. From these studies, scholars have gleaned insights into the influence of lobbying groups (Hertel-Fernandez 2014; Garrett and Jansa 2015; Riverstone-Newell 2017; Van Wilpert 2017); the role of model 
This is an author-produced, peer-reviewed version of this article. The final, definitive version of this document can be found online at Publius: The Journal of Federalism, published by Oxford University Press. Copyright restrictions may apply. doi: 10.1093/publius/pjz011

statutes in influencing legislative behavior (Hertel-Fernandez 2014); state legislators’ interest in opposing progressive ordinances passed by liberal cities (Greenblatt 2015); and the role of litigation and ballot initiatives as mechanisms to settle state-local conflicts (Rodd 2018).

We turn in this article to explain why some states adopt preemption laws more frequently than other states, which is a question that has been considered in other studies but has not yet been the subject of a systematic analysis. Riverstone-Newell (2017), in a prior contribution to the Publius Annual Review of American Federalism issue, argued that when conservatives dominate state legislatures, they are more likely to use preemption against liberal, progressive cities, but that local officials do not always comply with these laws and sometimes challenge them in court. This suggests a level of complexity in preemption activity that single policy area or single state studies have yet to capture. In light of this, our goal in this article is to identify which states are adopting preemption laws most frequently and consider explanations for variation in state preemption activity.

We first provide a brief discussion of key challenges researchers face when examining state preemption of local authorities, and identify seventeen policy areas in which preemption has been a particularly important issue in recent years. Second, we investigate why certain states are using preemption measures with particular frequency. Our conclusions indicate that political factors are more significant than institutional features in explaining preemption activity, but further research is necessary in order to better understand the relationship between preemption and distributions of state and local authorities, as well as its underlying antecedents.

\section{Identifying State Preemption Measures}

As scholars working in this area can attest, it can be difficult to determine which states have preempted the same activities or when preemption occurred, thereby creating a fundamental challenge for researchers (DuPuis, Langan, McFarland, Panettieri, and Rainwater 2017; Schragger 2017). In many cases, the legal bases of preemption are unclear, and mechanisms of enforcement can range from statutes, to crossover sanctions threatening revenue streams, and even to legal penalties for local officials violating preemption. Furthermore, some states have adopted multiple pieces of legislation that preempt local ordinances in the same area, which adds further complication (Schragger 2017). For example, several states, including Iowa, Louisiana, and Utah, appear to have adopted two firearms preemption statutes at different points in time (Giffords Law Center 2017). Scholars also encounter challenges in sorting through explicit preemption (i.e., when states explicitly reserve a given function for themselves) and implicit preemption (i.e., when state laws so completely controls a function that there is no room for local authorities) (Buzbee 2008).

Additionally, preemption may only apply to parts of a policy area, which further complicates inter-state comparisons. For instance, preemption of local ordinances addressing tobacco use among youth are somewhat common. However, some states only preempt ordinances related to advertising, while others preempt ordinances related to sales (Gorovitz, Mosher, and Pertschuk 1998). Furthermore, while states may preempt similar local activities, they may also apply somewhat different stipulations, which can alter the specific restrictions imposed. For example, twenty-six states preempt local ordinances to set housing prices altogether, but Texas's rent control preemption law provides a loophole that allows local governments to enact rent control ordinances if there is a housing emergency (Schragger 2017). Consequently, researchers run into the challenge of determining if all types of preemption activity are the same, or at least, if they can be reasonably grouped together for purposes of analysis.

Given these issues, we developed a two-step methodology to systematically identify and classify state restrictions on local authorities. First, we collected data from three recent studies conducted by non-profit organizations with an interest in state and local policy issues: 1) a 2017 report from the National League of Cities (NLC) based on data collected from secondary sources and a survey of state municipal leagues (DuPuis, Langan, McFarland, Panettieri, and Rainwater 2017); 2) a 2017 report from a joint project between A Better Balance and the Urban Law Center at Fordham University based on a legal analysis of a variety of progressive policy areas impacted by preemption (Schragger 2017); and, 3) a continuous effort by Grassroots Change to track state preemption actions on a set of public health-related policies (Grassroots Change 2018).

Second, we reviewed studies and identified policy subjects in which we could confirm findings either by an independent source or where study findings were well-documented enough that we could independently review the data. Then, we eliminated any policy categories in which there were inconsistencies between sources (or where inconsistencies could not be easily rectified) or in which we could not confirm the data. In other words, we confirmed 
This is an author-produced, peer-reviewed version of this article. The final, definitive version of this document can be found online at Publius:

The Journal of Federalism, published by Oxford University Press. Copyright restrictions may apply. doi: 10.1093/publius/pjz011

the identification and classification of state preemption policies used in these studies by either relying on other sources or reviewing data and determining if we could justifiably c determination regarding a state's preemption status for a specific policy subject, then it is reasonable to classify a state accordingly.

Based on this research, we identified seventeen usable categories of preemption subjects. These categories include a wide range of environmental, economic, social, and public health issues. Although this is not an exhaustive list and some areas of preemption are not included, there is a relatively high level of agreement concerning the status of states adopted preemption laws in regards to these subjects, which we believe mitigates some data reliability concerns.

It should be noted that the studies used as the basis of data collection for this article identify approximately twentythree additional subjects of preemption policies (although that number depends on how policies are defined). These include policies related to tax and/or expenditures limitations, tobacco (excluding smoke-free policies), climate change, education, contracting and/or employment practices, anti-discrimination (excluding creating new protected classes), immigration, and campaign finance. As noted above, a key problem that emerged is a vague definition of what is included in several of these categories; therefore, sources may have conflicted or it was difficult to verify findings. For instance, preemption of tobacco may include a range of policies regarding sales, marketing, and/or advertising of cigarettes, smokeless tobacco, or e-cigarettes. On the other hand, climate change preemption legislation restricts local governments from taking climate change into account, but what exactly that means or how it is articulated by local authorities is unclear. Additionally, there is a significant degree of nuance in preemption of tax and/or expenditure limitations and contracting and/or employment practices that make it difficult to make inter-state comparisons in these areas.

For various reasons, therefore, we focus for purposes of this article on preemption laws in areas where we have a reasonable degree of confidence about which states have adopted such measures and in a way that permits cross-state comparisons. The seventeen subject areas that we examine represent approximately half of the preempted subjects identified by leading studies, which we believe is sufficient to draw conclusions concerning overall preemption patterns.

\section{States and Preemption}

Table 1 lists the seventeen subjects of preemption that we identified, arranged in order of frequency of adoption and based on laws adopted as of 2017. On average, 17.9 states preempt local authority for each policy subject, with firearms restrictions being the most common (forty-three states), and anti-discrimination and fracking prohibitions being the least common (three states in each area). This list includes several issues with long legacies of policy debates, such as firearms, which first became the subject of preemption regulations several decades ago. Nevertheless, this list also includes other issues that have emerged more recently, such as the sharing economy and antidiscrimination (Greenblatt 2016). In general, there is a rather diverse set of policy issues that states have addressed via preemption laws, but these seventeen areas are the most commonly and thoroughly documented. Table 2 lists the number of preemption subjects by state, and Figure 1 maps the distribution across states. On average, states preempted 6.1 subjects, with Hawaii and New York preempting the fewest policies (one subject) and Florida, Tennessee, and Wisconsin preempting the most policies (twelve subjects).

\section{[Insert Table 1 here]}

\section{[Insert Table 2 here]}

\section{[Insert Figure 1 here]}

\section{Explanations}

Previous scholarship suggests several explanations for why certain states are more active than others in preempting local authority. The most basic and prominent explanation is related to the legal structure of state-local government relations and whether states operate under Dillon's Rule or Home Rule. In the former, states grant local governments authority in a piecemeal fashion and thereby create narrow spheres of local policy discretion. In the latter, local governments are semi-independent and enjoy broad policy discretion, although states can still use their superiority to rein in local authority (Krane, Rigos, and Hill 2011; Richardson 2011; Swindell, Stenberg, and Svara 2017). Consequently, states under Dillon's Rule doctrines can largely dictate the extent of local authority, which would 
This is an author-produced, peer-reviewed version of this article. The final, definitive version of this document can be found online at Publius: The Journal of Federalism, published by Oxford University Press. Copyright restrictions may apply. doi: 10.1093/publius/pjz011

generally make passage of preemption laws a superfluous action. On the other hand, Home Rule states generally must take action in order to limit local government action in certain policy areas, which would make preemption a key tool for states in managing state-local relations.

A second potential factor contributing to state-local conflict and leading to passage of preemption laws focuses on the balancing act between urban and rural areas. More specifically, state legislatures grapple with competing demands from urban and rural areas, leading to interesting power dynamics as states try to create (or claim to create) regulatory consistency (Williamson 2009; Stahl 2017). That is, policy challenges are different in large metropolitan cities than in smaller, less densely populated communities and can generate a variety of local regulatory approaches that create a patchwork of policy. In such a situation, state lawmakers may respond to pressure from constituents in rural areas who perceive a threat to cultural norms by enacting laws barring cities from regulating certain activities. On the other hand, constituents in cities may see behavior in rural areas as out of step with emerging norms and pressure lawmakers to centralize policy-making and abolish certain practices. As such, when there is a high degree of urban-rural conflict, state legislatures may need to create regulatory consistency as a compromise between the two sides.

A third explanation that is garnering increasing attention from scholars is that Republican-controlled states use preemption to stop liberal cities from adopting progressive policies. That is, municipal governments in a number of states are enacting progressive policies, which has put pressure on states to either adopt their own progressive policies or to preserve existing political and institutional patterns. For states choosing the latter option, preemption is a key tool to stifle local innovation and maintain state power. In other words, as states are being pushed by local governments, they are responding by curtailing local authorities in the hopes that it will stop (or at least slow) adoption of progressive policies. As such, preemption may just be another tactic in partisan conflict (Einstein and Glick 2017; Riverstone-Newell 2017). Texas serves as a prime example of this, where Republicans have controlled the state senate, house, and governor since 2000 (NCSL 2019). However, the cities of Austin, Dallas, Houston, El Paso, and San Antonio are largely Democratic strongholds, and adopt progressive policies in response to citizen demands (Myer 2013; Fisk 2016). Consequently, the Texas legislature has taken up an agenda of preemption in recent years in order to rein in these cities (Jayson 2018). To the extent that this pattern of conservative legislative responses to progressive local innovation is replicated in other states, we would expect preemption activity to be correlated with Republican strength in the state legislature (Riverstone-Newell 2017).

Fourth, because not all state legislatures have the same capacity for effective and responsive policymaking, some legislatures may be willing to allow local governments to take on the challenge of addressing policy isses in order to shift responsibility (Volden 2005). In general, citizen legislatures have few career politicians, whose primary focus is policymaking from which they have developed expertise and who have full-time staffs that research, negotiate, and write legislation. On the other hand, professional legislators have more time, resources, and expertise to dedicate to policy development, which makes them less reliant on external policy actors (e.g., local governments). Additionally, as full-time politicians, professional legislators are more acutely aware of political competition and its potential to undermine their power (Rosenthal 2001; Gray, Cluverius, Harden, Shor, and Lowery 2015). As such, professional legislatures may be less willing to allow local governments to venture into new policy areas and choose instead to centralize control. Conversely, citizen legislatures may be more willing to allow local governments to experiment with new policies in order to reduce their own work load and to avoid blame for controversial policy choices (Volden 2005). In contrast to some of the other explanations here, this would suggest that preemption activity is a result of institutional rather than political factors.

Finally, regional patterns that emerge in preemption activities (see Figure 1) suggest these trends may be a function of political culture, where existing beliefs related to government's role in political society have led states to rely on preemption to uphold existing norms. For instance, Elazar's (1984) conceptualization of political culture relies on the idea that states may define "good government" as either empowering the individual (individualistic cultures), pursuing the public good (moralistic cultures), or upholding an elitist system (traditionalistic cultures). As such, lawmakers in individualistic states may be more willing to allow decentralized approaches that can be curtailed to individual needs, as compared to those in moralistic or traditionalistic states who may be more concerned with broad ideals of the public good and existing systems of political power. Moreover, lawmakers in traditionalistic states in which "good government" is defined by maintaining existing institutions are likely to respond negatively to progressive policies in order to uphold political norms. As such, differences in how state lawmakers interpret local actions as aligning with ideals of "good government" may motivate them to prohibit certain actions. 
This is an author-produced, peer-reviewed version of this article. The final, definitive version of this document can be found online at Publius:

The Journal of Federalism, published by Oxford University Press. Copyright restrictions may apply. doi: 10.1093/publius/pjz011

\section{$\underline{\text { Data }}$}

We investigate the level of support for these explanations using an ordinary least squares (OLS) regression model, with the dependent variable being the number of subjects preempted by each state. (Diagnostic tests indicated no OLS assumptions were violated. Specifically, VIF scores indicated no multicollinearity, and White's test indicated no hetereoskedasticity). For predictor variables, we use the following variables to capture our five potential explanations. Descriptive statistics are provided in Table 3. While several predictors are time invariant, we measure other predictors based on available data after 2000, as it represents a modern political era and we believe that this most accurately captures political factors that explain contemporary trends in preemption adoptions. Nevertheless, the lack of temporal specificity in our data creates an analytical limitation.

\section{[Table 3 about here]}

First, to test the Home Rule explanation, we use a dummy variable comparing states under Home Rule doctrines (zero) to states under Dillion's Rule doctrines (one). Based on Krane, Rigos, and Hill (2001), we determined that ten states operate under a Home Rule doctrine, while forty states operate under Dillon's Rule (or a modified versions of Dillon's Rule). Although some nuances exist, this creates one of the most basic dichotomies in the legal relationship between state and local governments.

Second, to test the urban-rural explanation, we use the average percentage of state population living in urban areas between 2000 and 2010. With data from the two most recent US Censuses, we used the percentage from 2000 and 2010 to calculate the average during this time period (Census, 2019). Given that many rural-urban conflicts are exacerbated by urbanization, especially as it relates to rural- or urban-bias and the peri-urban fringe, this measure captures the prominence of urban areas as compared to non-urban areas (Simon 2008; Lichter and Brown 2011). This assumes that state legislatures serve as a key policymaking venues for rural interests that may be less organized or centralized than urban interests (Bell, Lloyd, and Vatovec 2010; Chen and Rodden 2013). In other words, in states with large urban populations, legislatures are likely to play a more active role in balancing urban and rural interests. On the other hand, in states with small urban populations, urban-rural differences are less politically polarizing, so state legislatures are not pressured to centralize control in order to reduce conflicts. We considered alternative measures, such as ratio of urban to rural populations; however, statistical diagnostic tests indicated urban population percentage is the best fit for our data.

Third, to test the partisanship explanation, we use the average percentage of Republicans serving in the state legislature between 2000 and 2017. Using data from Dubin (2007) and the National Conference of State Legislatures (NCSL 2019), we divided the number of seats held by Republicans by the total number of state legislative seats for each year, and then calculated the average across the eighteen years. We considered other measures of partisan control, including Republican control of the state senate, house, and/or governor's office. Tests of these measures yielded similar findings to those for percentage of Republicans in regards to the effects of partisanship on number of preemption subjects. However, percentage of Republicans provides a more nuanced test of partisan influence. Given that this explanation is grounded in partisan polarization, this measure allows us to consider whether more Republicans is correlated with more preemption, rather than whether Republican-control is correlated with more preemption. While previous research supports this explanation as it applies to Republican-controlled states (Riverstone-Newell 2017), using percentage of Republicans may provide additional insights into whether this explanation holds up when considering comparisons between states with Republican majorities, or states with Democratic majorities.

Fourth, to test the effect of legislative professionalism, we use an ordinal variable ranging from full-time professional legislatures (four) to part-time, citizen legislatures (zero) based on classification from the NCSL (NCSL 2017). NCSL classifies state legislatures based on the amount of time legislators dedicate to doing legislative work, their compensation, and the size of their professional staffs. Based on this, legislators in part-time, citizen legislatures spend the equivalent of less than half of a full-time job doing legislative work for little compensation and with relatively small professional staffs. On the other end of the spectrum, legislators in full-time, professional legislatures spend the equivalent of 80 percent or more of a full-time job on legislative work, are compensated enough so they do not have to seek outside income, and have relatively large staffs. Although other measures of legislative professionalism exist, their validity depends on the dimensions of professionalism and the time period for which they were developed (Mooney 1994; Squire 2007). However, Mooney (1994) indicates that there is a high degree of consistency across different measures. While not particularly sophisticated, the ordinal variable used here does capture the underlying concept that we are interested, where others may not be general enough and/or are outdated. 
This is an author-produced, peer-reviewed version of this article. The final, definitive version of this document can be found online at Publius: The Journal of Federalism, published by Oxford University Press. Copyright restrictions may apply. doi: 10.1093/publius/pjz011

Finally, to test the political culture explanation, we use Elazar's (1984) typology to create two dummy variables comparing Moralistic and Traditionalistic to Individualistic cultures. While Elazar (1984) provides more nuanced classifications for how political cultures are distributed across the U.s., other scholars have since labeled states as falling into one of these three types based on their dominant political cultures (see Smith, Greenblatt, and Buntin 2018, 12). Although Elazar's typology has been criticized on both theoretical and methodological grounds and other measures of political culture exist, it remains one of the most commonly used measures of political culture in comparative state policy research (Fitzgerald and Hero 1988; Wirt 1991; Lieske 2010). To this end, numerous scholars have used this typology to explain policy adoptions related to issues such as welfare reform (Mead 2004), renewable energy (Fowler and Breen 2013, 2014), pay equity (Reese and Warner 2012), higher education (Heck, Lam, and Thomas 2014), and healthcare (Fossett and Thompson 2006). As such, our measure of political culture is consistent with previous scholarship.

\section{Findings}

Table 4 displays the results of the OLS model and indicates support for four of the five explanations. Specifically, states with Home Rule doctrines, a higher percentage of Republican state legislators, more professionalized legislatures, or Moralistic or Traditionalistic political cultures are likely to have preempted more subjects than other states. Although a positive coefficient indicates that states with higher urban populations preempt more subjects, the lack of statistical significance means we cannot be certain of the impact of urban-rural conflict on preemption activity. Given the recent media accounts of preemption activity, these findings are not particularly surprising, but they do provide some more substantive data to support existing explanations. Additionally, standardized coefficients indicate that partisan legislative control and political culture are the strongest predictor of preemption activity, while Home Rule and citizen legislatures are among the weakest predictors in the model. As a whole, this may suggest that institutional features are less important in predicting preemption activity from states than political factors. Finally, the $\mathrm{R}^{2}$ and adjusted $\mathrm{R}^{2}$ indicate that our model is a strong predictor of the number of preempted subjects by state.

\section{[Table 4 about here]}

\section{Discussion and Conclusion}

Our investigation of state use of preemption provides some support for several key explanations previously suggested. In general, it appears that politically conservative states are the most likely to use preemption, although institutional features like Home Rule and legislative professionalism also contribute to this activity. Furthermore, the regional patterns that emerge in figure 1 tell a similar story about which kinds of states are using preemption more frequently. Generally, we can infer from these findings that conservative states use preemption to rein in local authority that may be challenging traditional political norms. Of course, this finding largely aligns with previous research concerning conflict between conservative states and progressive cities (Riverstone-Newell 2017). However, we provide two key contributions. First, our analysis relies on a dataset that includes preemption across seventeen policy subjects, which is one of the most comprehensive listings of preemption activity by state in recent literature. As this provides a broader perspective than extant scholarship, we can conclude that these trends are not limited to specific states or preemption subjects. Second, our findings indicate that preemption is better explained by political factors than institutional features, which would suggest that recent preemption activity is likely a result of increasing political competition and/or partisan polarization. Given that institutional features like legislative professionalism and Home Rule doctrines are long-standing, this would also suggest that contemporary trends in preemption are a departure from the past.

Nevertheless, since we rely on cross-sectional data, our inferences are limited to correlations between state political dynamics and preempted policy subjects. The temporal aspect here is important as state political dynamics have shifted over the last several decades (Fiorina, 1997; Stonecash and Agathangelou 1997; Shufeldt and Flavin 2012). As such, it is difficult to determine if Republican-controlled state legislatures are more likely to adopt preemption measures, or if Republicans are more likely to control legislatures in states with a history of adopting preemption measures. Our findings also do not account for whether preemption is more common historically in states with professional legislatures, who used it under different political and administrative circumstances, or if professional legislatures are still using preemption more frequently than other state legislatures. Additionally, given the small nsize, our findings are not robust, which increases the likelihood of type- 1 and type-2 statistical error. Furthermore, perspectives on intergovernmental relations tend to look different when taking a top-down as compared to a bottom- 
This is an author-produced, peer-reviewed version of this article. The final, definitive version of this document can be found online at Publius: The Journal of Federalism, published by Oxford University Press. Copyright restrictions may apply. doi: 10.1093/publius/pjz011

up view (McGuire 2006; Bowman and Kearney 2011). Consequently, our analysis is also limited by our reliance on state-level data that does not incorporate local policy innovation, regulatory consistency, or intra-state political polarization.

While preemption has long been a tool for state legislators to constrain local authority, current trends in use of preemption appear to depart from traditional patterns. More specifically, the rise in state preemption in recent years appears to be connected to increased political competition more so than allocating policy responsibilities in such a way that it produces the best public services (Volden 2005). Although previous scholarship indicates partisanship is also a significant driver in federal preemption of state authority, trends at the state-level appear to be different. More specifically, SoRelle and Walker (2016) find that Congressional Democrats adopt preemption at a similar rate as Republicans, albeit for different purposes. However, we find no evidence that Democrats in state legislators are engaging in similar behavior as Republicans. Most likely, this is because Congressional Republicans and Democrats battle vertical political competition from both liberal and conservative states; on the other hand, municipalities engaging in policy innovation tend be overwhelmingly liberal and create more competition for Republican than Democratic state legislatures. While the predominant focus of federalism scholars has been on federal-state conflicts, "recent disputes between state and local officials' rival federal-state battles in their intensity" (Riverstone-Newell 2017, 420). As such, state-local conflict may represent not only the new battlefield of federalism, but also an emerging battlefield in the partisan polarization war. If true, this may partially explain both the surge in state preemption activities and in local policy innovation in recent decades (Bowman 2017; Langan and McFarlan 2017).

While further research is necessary to examine these patterns, variation across states in preemption suggests that there may be divergent philosophies of state and local authorities emerging due to political differences. In other words, the underlying philosophy of which policy authorities lie with states or with local governments may be fundamentally different in more traditional, conservative states than more progressive, liberal states. Consequently, power distributions between state and local governments are likely shifting as well, which requires us to reconsider extant models of intergovernmental relations. Importantly, this may also further hint at how political polarization is affecting not only our political discourses but also our political institutions, where state-local relations may look fundamentally different in conservative states than in liberal states. Several scholars have already produced important work on this front, noting the increasingly innovative roles that local governments are playing and offering explanations of what has spurred these trends (e.g., Feiock and Scholtz 2009; Riverstone-Newell 2017). However, there is still a need to examine preemption using more systematic methods in order to comprehend how institutions and legal authorities have shifted in response to political conflicts. As such, the sort of research presented in this article is a key step in furthering this agenda as it begins to unpack key dimensions of preemption trends.

Acknowledgements: The authors would like to thank Publius editor, John Dinan, whose comments helped to improve the final quality of the text.

\section{References}

Albino, V., U. Berardi, and R.M. Dangelico. 2015. Smart Cities: Definitions, Dimensions, Performance, and Initiatives. Journal of Urban Technology 22(10): 3-21.

American Legislative Exchange Council. 2019. Model Policies. https://www.alec.org/model-policy/ (Accessed March 1, 2019).

Associated Press. 2019. New Mexico blocks right-to-work ordinances. March 28. https://www.apnews.com/23d19d56b72541b2a151aa0cddc9396c (accessed April 1, 2019).

Bell, M.M., S.E. Lloyd, and C. Vatovec. 2010. Activating the Countryside: Rural Power, the Power of the Rural, and the Making of Rural Politics. Sociologia Ruralis 50(3): 205-224.

Berman, D. R. 2018. The State and the Cities: Working Out the Relationship. Arizona State University Morrison Institute for Public Policy. https://morrisoninstitute.asu.edu/sites/default/files/content/products/CITY\%20\%26\%20STATE_0.pdf (Accessed March 1, 2019).

Bergal, J. 2015. Cities Forge Policy Apart from States. Stateline: Pew Charitable Trusts, January 15. https://www.pewtrusts.org/en/research-and-analysis/blogs/stateline/2015/1/15/cities-forge-policy-apartfrom-states. (Accessed March 1, 2019).

Borras, S. 2011. Policy Learning and Organizational Capacities in Innovation Policies. Science \& Public Policy 38(9): 725-734. 
This is an author-produced, peer-reviewed version of this article. The final, definitive version of this document can be found online at Publius: The Journal of Federalism, published by Oxford University Press. Copyright restrictions may apply. doi: 10.1093/publius/pjz011

Bowman, A. O’M. 2017. The State-local Government(s) Conundrum: Power and Design. Journal of Politics 79(4): $1119-1129$.

Bowman, A. O’M. and R.C. Kearney. 2011. Second-Order Devolution: Data and Doubt. Publius: The Journal of Federalism 41(4): 563-85.

Briffault, R. 2018. The Challenge of the New Preemption. Stanford Law Review 70: 1995-2017.

Burke, M. 2019. State Bill Aims to Block Cities from Regulating Plastic Bags. The Norman Transcript, March 10. https://www.normantranscript.com/news/local_news/state-bill-aims-to-block-cities-from-regulating-plasticbags/article_a68adcf9-b9c5-5761-8f57-e338132a327f.html (Accessed March 15, 2019)

Buzbee, W.W. ed. 2008. Preemption Choice: The Theory, Law, and Reality of Federalism's Core Question. New York: Cambridge University Press.

Chen, J. and J. Rodden. 2013. Unintentional Gerrymandering: Political Geography and Electoral Bias in Legislatures. Quarterly Journal of Political Science 8: 239-269.

Dubin, M. 2007. Party Affiliations in the State Legislatures: A Year by Year Summary. Jefferson, NC: McFarland \& Company.

DuPuis, N., T. Langan, C. McFarland, A. Panettieri, and B. Rainwater. 2017. City Rights in an Era of Preemption: A State-by-State Analysis. National League of Cities. http://nlc.org/sites/default/files/201702/NLC\%20Preemption\%20Report\%202017.pdf (Accessed March 1, 2019).

Einstein, K.L. and D.M. Glick. 2017. Cities in American Federalism: Evidence on State-Local Government Conflict from a Survey of Mayors. Publius: The Journal of Federalism 47(4): 599-621.

Elazar, D. 1984. American Federalism: A View from the States, $3^{\text {rd }}$ ed. New York: Harper \& Row.

Feiock, R.C. and J.T. Scholtz. 2009. Self-Organizing Governance of Institutional Collective Action Dilemmas: An Overview. In Self-Organizing Federalism: Collective Mechanisms to Mitigate Institutional Collective Action Dilemmas eds. R.C. Feiock and J.T. Scholtz: 3-32. New York: Cambridge University Press.

Fiorina, M.P. 1997. Professionalism, Realignment, and Representation. American Political Science Review 91(1): 156-162.

Fisk, J.M. 2016. Fractured Relationships: Exploring Municipal Defiance in Colorado, Texas, and Ohio. State \& Local Government Review 48(2): 75-86.

Fitzgerald, J.L. and R.E. Hero. 1988. Political Culture and Political Characteristics of the American States: A Consideration of Some Old and New Questions. Western Political Quarterly 41(1): 145-153.

Fossett, J. and F.J. Thompson. 2006. Administrative Responsiveness to the Disadvantaged: The Case of Children's Health Insurance. Journal of Public Administration Research \& Theory 16(3): 369-392.

Fowler, L. and J. Breen. 2013. The Impact of Political Factors on States’ Adoption of Renewable Portfolio Standards. The Electricity Journal 26(2): 79-94.

Fowler, L. and J. Breen. 2014. Political Influences and Financial Incentives for Renewable Energy. The Electricity Journal 27(1): 74-84.

Garrett, K.N. and J. M. Jansa. 2015. Interest Group Influence in Policy Diffusion Networks. State Politics and Policy Quarterly, XX: 1-31.

Giffords Law Center. 2017. Preemption State by State. https:/lawcenter.giffords.org/gun-laws/state-law/50-statesummaries/preemption-state-by-state/ Accessed March 1, 2019

Gorovitz, E., J. Mosher, and M. Pertschuk. 1998. Preemption or Prevention? Lessons from Efforts to Control Firearms, Alcohol, and Tobacco. Journal of Public Health Policy 19(1): 36-50.

Grassroots Change. 2018. Preemption Watch. https://grassrootschange.net/preemption-watch/ (Accessed March 1, 2019).

Gray, K. 2016. Plastic Bags Fuel Tug of War Between State, Locals. Detroit Free Press, May 9. https://www.freep.com/story/news/politics/2016/05/09/plastic-bags-fuel-tug-war-between-statelocals/84156192/ [Accessed March 1, 2019].

Gray, V., J. Cluverius, J.J. Harden, B. Shor, and D. Lowery. 2015. Party Competition, Party Polarization, and the Changing Demand for Lobbying in the American States. American Politics Research 43(2): 175-204.

Greenblatt, A. 2015. From Campaign Finance to Pot, Progressives Look to Local Voters. Governing, October 2. http://www.governing.com/topics/politics/gov-local-ballot-measures-election-2015.html (Accessed March 1, 2019).

Greenblatt, A. 2016. Beyond North Carolina’s LGBT Battle: States’ War on Cities. Governing, March 25. http://www.governing.com/topics/politics/gov-states-cities-preemption-laws.html (Accessed March 1, 2019). 
This is an author-produced, peer-reviewed version of this article. The final, definitive version of this document can be found online at Publius: The Journal of Federalism, published by Oxford University Press. Copyright restrictions may apply. doi: 10.1093/publius/pjz011

Grimm, F. 2019. Florida Legislature’s Latest Preemption Frenzy Would Sabotage Plastic Straw Ban. Sun Sentinel, March 8. https://www.sun-sentinel.com/opinion/fl-op-grimm-plastic-straws-20190307-story.html (Accessed March 15, 2019).

Hall, J.L. 2007. Developing Historical 50-State Indices of Innovation Capacity and Commercialization Capacity. Economic Development Quarterly 21(2): 107-123.

Hall, J.L. and M.E. Howell-Moroney, 2012. Poverty, Innovation Capacity, and State Economic Development in the Knowledge Economy: Evidence from the U.S. Growth \& Change 43(2): 228-251.

Haughey, J. 2019. Two Bills Seek State Preemption in Regulating Vacation Rentals. Florida Watchdog, February 18. https://www.watchdog.org/florida/two-bills-seek-state-preemption-in-regulating-vacationrentals/article_3235cb4e-338d-11e9-b9a9-c36cf61ab0ae.html. (Accessed March 15, 2019).

Hartley, J. 2005. Innovation in Governance and Public Services: Past and Present. Public Money \& Management 25(1): 27-34.

Heck, R.H., W.S. Lam, and S.L. Thomas. 2014. State Political Culture, Higher Education Spending Indicators, and Undergraduate Graduation Outcomes. Educational Policy 28(1): 3-39.

Hertel-Fernandez, Alexander. 2014. Who Passes Business’s “Model Bills”? Policy Capacity and Corporate Influence in U.S. State Politics. Perspectives on Politics, 12 (3): 587.

Hicks, W.D. et al. 2018. Home Rule Be Damned: Exploring Policy Conflicts between the Statehouse and City Hall. PS: Political Science \& Politics 51(1): 26-38.

Jayson, S. 2018. In the Lone Star State, Cities Feel the Heat. US News \& World Report, December 27. https://www.usnews.com/news/best-states/articles/2018-12-27/cities-versus-state-a-battle-for-control-inthe-texas-legislature. (Accessed March 15, 2019).

Krane, D., N. Rigos, and M. Hill. 2001. Home Rule in America: A Fifty-State Handbook. Washington, DC: CQ Press.

Krause, R.M. 2011. Policy Innovation, Intergovernmental Relations, and the Adoption of Climate Protection Initiatives by U.S. Cities. Journal of Urban Affairs 33(1): 45-60.

Langan, T.J. and C.K. McFarland. 2017. City Leadership, City Constraints. State \& Local Government Review 49(4): 267-274.

Lee, S.Y., R. Florida, and G. Gates. 2010. Innovation, Human Capital, and Creativity. International Review of Public Administration 14(3): 13-24.

Lichter, D.T. and D.L. Brown. 2011. Rural America in an Urban Society: Changing Spatial and Social Boundaries. Annual Review of Sociology 37: 565-592.

Lieske, J. 2010. The Changing Regional Subcultures of the American States and the Utility of a New Cultural Measure. Political Research Quarterly 63(3): 538-552.

McGuire, M. 2006. Intergovernmental Management: A View from the Bottom. Public Administration Review 66(5): 677-79.

Mead, L.M. 2004. State Political Culture and Welfare Reform. Policy Studies Journal 32(2): 271-296.

Mooney, C.Z. 1994. Measuring U.S. State Legislative Professionalism: An Evaluation of Five Indices. State \& Local Government Review 26(2): 70-78.

Mosher, J. 2017. Review of State Laws Restricting Local Authority to Impose Alcohol Taxes in the United States. Journal of Studies on Alcohol and Drugs 78 (2): 241-248.

Myer, A.S. 2013. Secular Geographical Polarization in the American South: The Case of Texas 1996-2010. Electoral Studies 32(1): 48-62.

National Conference of State Legislatures. 2017. Full- and Part-time Legislatures. http://www.ncsl.org/research/about-state-legislatures/full-and-part-time-legislatures.aspx (Accessed March 1, 2019).

National Conference of State Legislatures. 2019. State Partisan Composition. http://www.ncsl.org/research/aboutstate-legislatures/partisan-composition.aspx (Accessed March 15, 2019).

Nelson, T. 2018. Local Control v. Statewide Standard - Battle Over Preemption Continues. MPR News, March 29. https://www.mprnews.org/story/2018/03/29/local-control-v-statewide-standard-battle-over-preemptioncontinues (Accessed March 15, 2019)

Phillips, L.E. 2018. Impeding Innovation: State Preemption of Progressive Local Regulations. Columbia Law Review 117 (8): 2225-2263.

Rabe, B. 2008. States on Steroids: The Intergovernmental Odyssey of American Climate Policy. Review of Policy Research 25(2): 105-128.

Reese, C.C. and B. Warner. 2012. Pay Equity in the States: An Analysis of the Gender-Pay Gap in the Public Sector. Review of Public Personnel Administration 32(4): 312-331. 
This is an author-produced, peer-reviewed version of this article. The final, definitive version of this document can be found online at Publius:

The Journal of Federalism, published by Oxford University Press. Copyright restrictions may apply. doi: 10.1093/publius/pjz011

Richardson, J.J. 2011. Dillon’s Rule is From Mars, Home Rule is From Venus: Local Government Autonomy and the Rules of Statutory Construction. Publius: The Journal of Federalism 41(4): 662-685.

Riverstone-Newell, L. 2017. The Rise of State Preemption Laws in Response to Local Policy Innovation. Publius: The Journal of Federalism 47 (3): 403-425.

Rodd, S. 2018. Banning the Bans: State and Local Officials Clash Over Plastic Bags. Stateline. January 29.

Rosenthal, A. 2001. The Third House: Lobbyists and Lobbying in the States, 2nd ed. Washington, DC: CQ Press.

Schragger, R. 2017. State Preemption of Local Laws: Preliminary Review of Substantive Areas. https://www.abetterbalance.org/wp-content/uploads/2017/08/State-Preemption-of-Local-Laws.pdf (Accessed March 1, 2019).

Shufeldt, G. and P. Flavin. 2012. Two Distinct Concepts: Party Competition in Government and Electoral Competition in the American States. State Politics \& Policy Quarterly 12(3): 330-342.

Simon, D. 2008. Urban Environments: Issues on the Peri-Urban Fringe. Annual Review of Environment \& Resources 33: 167-185.

Smith, K.B., A. Greenblatt, and J. Buntin. 2018. Governing States \& Localities, 6th ed. Washington, DC: CQ Press.

Sneve, J. 2019. Bill Aimed at Killing Sioux Fall's Stolen Gun Registry Awaits Gov. Noem's Signature. Argus Leader, February 22. https://www.argusleader.com/story/news/politics/2019/02/22/fate-sioux-falls-stolengun-registry-unclear-after-passage-hb-1056/2944988002/ (Accessed March 15, 2019).

SoRelle, Mallory, and Alexis N. Walker. 2016. Partisan Preemption: The Strategic Use of Federal Preemption Legislation. Publius; The Journal of Federalism 46(4): 486-509

Squire, P. 2007. Measuring State Legislative Professionalism: The Squire Index Revisited. State Politics \& Policy Quarterly 7(2): 211-227.

Stahl, K, A. 2017. Preemption, Federalism, and Local Democracy. Fordham Law Journal 44: 133-179.

Stonecash, J.M. and A.M. Agathangelou. 1997. Trends in the Partisan Composition of State Legislatures: A Response to Fiorina. American Political Science Review 91(1): 148-155.

Swindell, D., C. Stenberg, and J. Svara. 2017. Navigating the Waters between Local Autonomy and State Preemption. Research Report, Alliance for Innovation. https://urbaninnovation.asu.edu/sites/default/files/2017_big_ideas_work_paper_0.pdf

U.S. Census. 2019. Statistical Abstract Series. https://www.census.gov/library/publications/timeseries/statistical_abstracts.html (Accessed March 15, 2019).

Volden, C. 2005. Intergovernmental Political Competition in American Federalism. American Journal of Political Science 49(2): 327-42.

Von Wilpert, M. 2017. City Governments Are Raising Standards for Working People - and State Legislators are Lowering Them Back Down. Economic Policy Institute, August 26. https://www.epi.org/publication/citygovernments-are-raising-standards-for-working-people-and-state-legislators-are-lowering-them-backdown/ (Accessed March 15, 2019).

Williamson, D. 2009. Urbanites versus Rural Rights: Contest of Local Government Land-Use Regulations Under Washington Preemption Statute 82.02.020. Washington Law Review 84: 491.

Wirt, F.M. 1991. "Soft” Concepts and "Hard” Data: A Research Review of Elazar’s Political Culture. Publius: The Journal of Federalism 21 (2): 1-13.

Wynen, J., K. Verhoest, E. Ongaro, and S. van Thiel. 2014. Innovation-Oriented Culture in the Public Sector: Do Managerial Autonomy and Result Control Lead to Innovation. Public Management Review 16 (1): 45-66. 
This is an author-produced, peer-reviewed version of this article. The final, definitive version of this document can be found online at Publius: The Journal of Federalism, published by Oxford University Press. Copyright restrictions may apply. doi: 10.1093/publius/pjz011

Table 1. Subjects of Preemption by Frequency of State Adoption

\begin{tabular}{|c|c|c|}
\hline Subject & Description & $\begin{array}{c}\text { Count } \\
\text { of } \\
\text { states }\end{array}$ \\
\hline Firearms & $\begin{array}{l}\text { Restricts local regulation of firearm or ammunition sales, possession, or usage } \\
\text { (Schragger 2017; Grassroots Change 2018) }\end{array}$ & 43 \\
\hline Sharing economy & $\begin{array}{l}\text { Restricts local regulatory power over ride hailing platforms (e.g., Uber) or short-term } \\
\text { rental/home sharing platforms (e.g., Airbnb) (DuPuis, et al. 2017; Schragger 2017) }\end{array}$ & 37 \\
\hline Pesticides & $\begin{array}{l}\text { Prohibits local regulation of pesticide sale or use, including marketing, distribution, } \\
\text { training, or storage and disposal (Schragger 2017) }\end{array}$ & 30 \\
\hline Rent control & Prohibits local authority to set rental prices for private housing units (Schragger 2017) & 26 \\
\hline Minimum wage & $\begin{array}{l}\text { Prohibits local governments from establishing a minimum wage that exceeds minimums } \\
\text { established by state or federal laws (DuPuis, et al. 2017; Schragger 2017) }\end{array}$ & 24 \\
\hline $\begin{array}{l}\text { Dog breed } \\
\text { limitations }\end{array}$ & $\begin{array}{l}\text { Prohibits local ordinances that ban ownership of certain dogs that may be perceived as } \\
\text { dangerous based on breed (Schragger 2017) }\end{array}$ & 19 \\
\hline $\begin{array}{l}\text { Municipal } \\
\text { broadband }\end{array}$ & $\begin{array}{l}\text { Either explicit prohibition of public entities providing broadband services, or procedural } \\
\text { barriers that significantly restrict local capacity to pursue public broadband services (e.g., } \\
\text { required ballot initiatives or feasibility studies) (DuPuis, et al. 2017) }\end{array}$ & 17 \\
\hline Paid leave & $\begin{array}{l}\text { Prohibits local governments from requiring employers to provide paid sick leave or } \\
\text { vacation days to employees beyond state or federal requirements (DuPuis, et al. 2017; } \\
\text { Schragger 2017; Grassroots Change 2018) }\end{array}$ & 17 \\
\hline Fire sprinklers & $\begin{array}{l}\text { Prohibits local requirements of fire sprinklers in residential dwellings (Grassroots } \\
\text { Change 2018) }\end{array}$ & 16 \\
\hline Factory farms & $\begin{array}{l}\text { Restricts local zoning ordinances related to agricultural production (Schragger, 2017; } \\
\text { Grassroots Change 2018) }\end{array}$ & 13 \\
\hline $\begin{array}{l}\text { Employee } \\
\text { benefits }\end{array}$ & $\begin{array}{l}\text { Prohibits local governments from requiring employers to provide employee benefits (i.e., } \\
\text { healthcare insurance) to employees beyond state or federal requirements (Schragger } \\
\text { 2017) }\end{array}$ & 12 \\
\hline Smoke-free & $\begin{array}{l}\text { Prohibits local ordinances related to smoking in public places or commercial venues } \\
\text { (Grassroots Change 2018) }\end{array}$ & 12 \\
\hline Nutrition & $\begin{array}{l}\text { Restricts local regulatory authority over portion sizes, as well as incentives to promote or } \\
\text { reduce usage of any type of food, nutrition, or farming (Schragger, 2017; Grassroots } \\
\text { Change 2018) }\end{array}$ & 11 \\
\hline $\begin{array}{l}\text { Inclusionary } \\
\text { zones }\end{array}$ & $\begin{array}{l}\text { Prohibits local requirements for private developers to include affordable housing units } \\
\text { within projects (Schragger 2017) }\end{array}$ & 10 \\
\hline Plastic bags & $\begin{array}{l}\text { Restricts local authority to regulate the use of plastic bags, including usage fees } \\
\text { (Schragger 2017) }\end{array}$ & 10 \\
\hline Discrimination & $\begin{array}{l}\text { Prohibits local governments from extending protections surrounding employment, use of } \\
\text { public facilities, or commercial activities to protected classes not recognized by state law } \\
\text { (DuPuis, et al. 2017; Schragger 2017; Grassroots Change 2018) }\end{array}$ & 3 \\
\hline Fracking & $\begin{array}{l}\text { Prohibits local regulation of hydraulic fracturing used in oil and gas operations } \\
\text { (Schagger 2017) }\end{array}$ & 3 \\
\hline
\end{tabular}

Source: Authors' calculations based on data drawn from DuPuis, et al. 2017; Schragger 2017; Grassroots Change 2018. 
This is an author-produced, peer-reviewed version of this article. The final, definitive version of this document can be found online at Publius:

The Journal of Federalism, published by Oxford University Press. Copyright restrictions may apply. doi: 10.1093/publius/pjz011

Table 2. Number of Preempted Subjects per State

\begin{tabular}{|c|c|c|c|}
\hline State & $\begin{array}{c}\text { Number of } \\
\text { Preempted Subjects }\end{array}$ & State & $\begin{array}{c}\text { Number of } \\
\text { Preempted Subjects }\end{array}$ \\
\hline Alabama & 8 & Montana & 3 \\
Alaska & 2 & Nebraska & 4 \\
Arizona & 11 & Nevada & 5 \\
Arkansas & 7 & New Hampshire & 9 \\
California & 4 & New Jersey & 3 \\
Colorado & 9 & New Mexico & 4 \\
Connecticut & 3 & New York & 1 \\
Delaware & 2 & North Carolina & 11 \\
Florida & 12 & North Dakota & 6 \\
Georgia & 9 & Ohio & 4 \\
Hawaii & 1 & Oklahoma & 9 \\
Idaho & 8 & Oregon & 6 \\
Illinois & 4 & Pennsylvania & 9 \\
Indiana & 7 & Rhode Island & 5 \\
Iowa & 5 & South Carolina & 5 \\
Kansas & 10 & South Dakota & 6 \\
Kentucky & 5 & Tennessee & 12 \\
Louisiana & 6 & Texas & 7 \\
Maine & 3 & Utah & 8 \\
Maryland & 4 & Vermont & 2 \\
Massachusetts & 3 & Virginia & 8 \\
Michigan & 11 & Washington & 3 \\
Minnesota & 6 & West Virginia & 3 \\
Mississippi & Wisconsin & 2 \\
Missouri & Wyoming & 2 \\
\hline
\end{tabular}

Source: Authors' calculations based on data drawn from DuPuis, et al. 2017; Schragger 2017; Grassroots Change 2018. 
This is an author-produced, peer-reviewed version of this article. The final, definitive version of this document can be found online at Publius:

The Journal of Federalism, published by Oxford University Press. Copyright restrictions may apply. doi: 10.1093/publius/pjz011

Table 3. Variable Descriptive Statistics

\begin{tabular}{|c|l|c|c|c|c|}
\hline Variable & \multicolumn{1}{|c|}{ Description } & $\begin{array}{c}\text { Mean } \\
\text { (or \%) }\end{array}$ & St. Dev. & Min & Max \\
\hline $\begin{array}{c}\text { Preempted Subjects } \\
\text { (DV) }\end{array}$ & Count of preempted subjects by state & 6.319 & 3.065 & 1 & 12 \\
\hline Home Rule & $\begin{array}{l}\text { Dummy variables comparing states with } \\
\text { Dillon's Rule status to Home Rule status } \\
\text { (Krane, Rigos, and Hill 2000) }\end{array}$ & .787 & .414 & 0 & 1 \\
\hline $\begin{array}{c}\text { Republican } \\
\text { Legislature }\end{array}$ & $\begin{array}{l}\text { Average percentage of Republicans in state } \\
\text { legislature between 2000 and 2017 (NCSL } \\
\text { 2019) }\end{array}$ & .509 & .143 & .142 & .801 \\
\hline $\begin{array}{c}\text { Legislative } \\
\text { Professionalism }\end{array}$ & $\begin{array}{l}\text { Ordinal variable comparing states with } \\
\text { professional legislatures to citizen } \\
\text { legislatures (NCSL 2019) }\end{array}$ & 1.920 & .986 & 0 & 4 \\
\hline $\begin{array}{c}\text { Urban Population } \\
\text { Average percentage of state population } \\
\text { living in urban areas between 2000 and 2010 } \\
\text { Census (Census 2019) }\end{array}$ & 72.407 & 14.887 & 38.550 & 94.700 \\
\hline $\begin{array}{c}\text { Moralistic Political } \\
\text { Culture }\end{array}$ & $\begin{array}{l}\text { Dummy variable comparing states with } \\
\text { dominant Moralistic cultures to other states } \\
\text { (Smith, Greenblatt, and Buntin 2018) }\end{array}$ & .361 & .486 & 0 & 1 \\
\hline $\begin{array}{c}\text { Traditionalistic } \\
\text { Political Culture }\end{array}$ & $\begin{array}{l}\text { Dummy variable comparing states with } \\
\text { dominant Traditionalistic cultures to other } \\
\text { states (Smith, Greenblatt, and Buntin 2018) }\end{array}$ & .361 & .486 & 0 & 1 \\
\hline
\end{tabular}

Table 4. OLS Regression Model of Preemption Subject Count

\begin{tabular}{|l|l|l|}
\hline & Coefficients & Standardized Coefficients \\
\hline Home Rule & $1.756(.838)^{*}$ & .237 \\
Republican Legislature & $11.265(2.537)^{* * *}$ & .525 \\
Legislative Professionalism & $1.223(.387)^{* *}$ & .396 \\
Urban Population & $.008(.027)$ & .038 \\
Moralistic Political Culture & $2.558(.932)^{* *}$ & .405 \\
Traditionalistic Political Culture & $3.542(.884)^{* * *}$ & .561 \\
\hline Constant & .784 & \\
$\mathrm{R}^{2}$ & .530 & \\
Adjusted $\mathrm{R}^{2}$ & .459 & \\
$\mathrm{~N}$ & $47^{\mathrm{a}}$ & \\
\hline
\end{tabular}

Note: $*<.05, * *<.01, * * *<.001$. Standard errors are reported in parentheses.

${ }^{a}$ Three states were dropped from the analysis due to missing data. Nebraska has a non-partisan legislature, and Elazar (1984) does not include a political culture classification for Alaska or Hawaii. 
This is an author-produced, peer-reviewed version of this article. The final, definitive version of this document can be found online at Publius: The Journal of Federalism, published by Oxford University Press. Copyright restrictions may apply. doi: 10.1093/publius/pjz011

Figure 1. Distribution of Preempted Subjects Across States

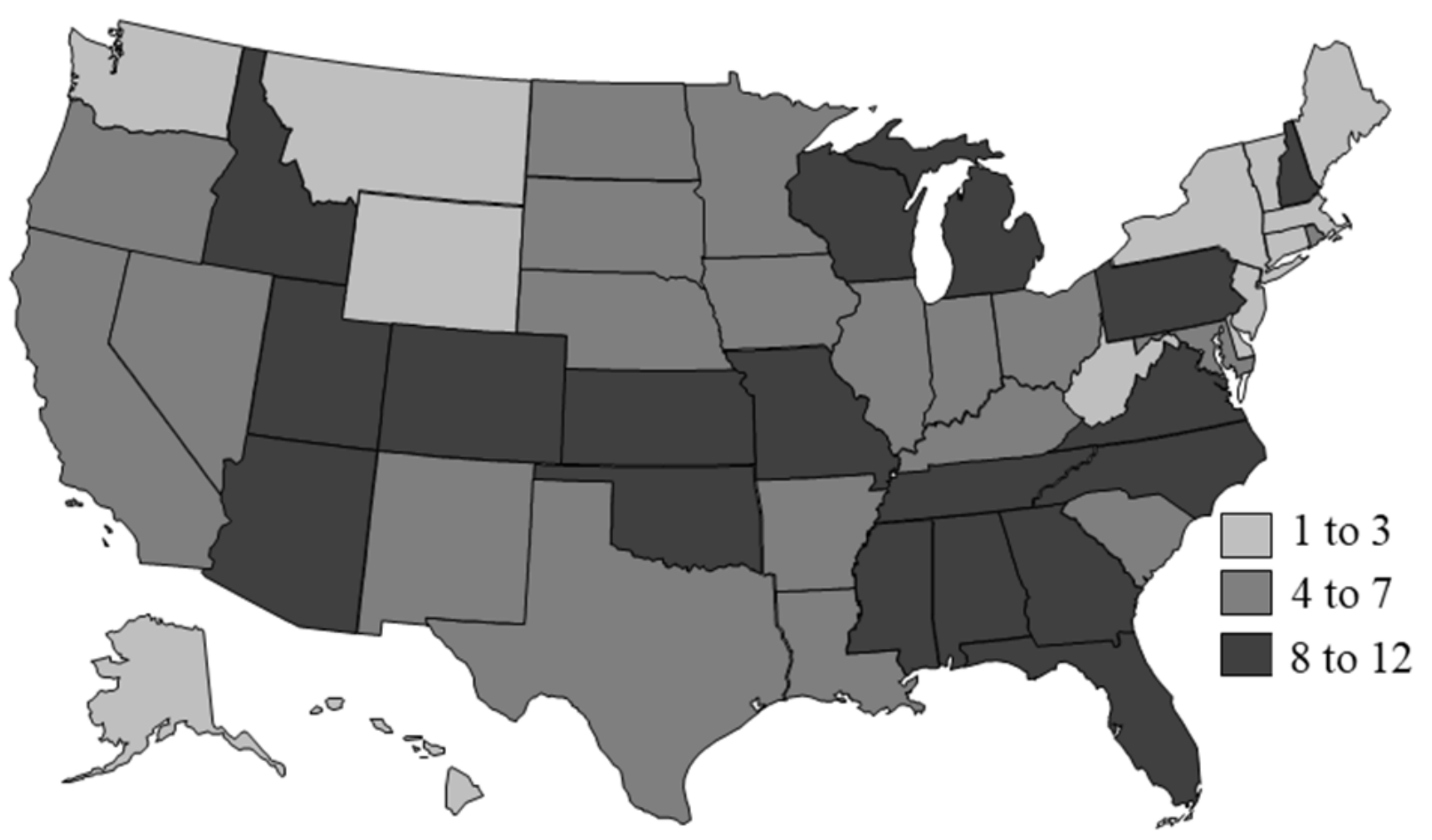

Source: Authors' calculations based on data drawn from DuPuis, et al. 2017; Schragger 2017; Grassroots Change 2018. 